Jurnal Litbang Sukowati, Vol. 4, No. 1, November 2020, Hal 101-111 p-ISSN: 2580-541X, e-ISSN: $2614-3356$

\title{
LABOR PRODUCTIVITY, NUMBER OF MOTOR VEHICLE AND INCOME CONVERGENCE
}

\begin{tabular}{|c|}
\hline Joko Susanto \\
Faculty of Economics and Business, UPN "Veteran" Yogyakarta \\
jk.susanto.68@gmail.com
\end{tabular}

Diterima: Mei 2020; Disetujui: Oktober 2020

\begin{abstract}
This research examines the occurrence of income convergence in the Surakarta Ex-Residency. Data included per capita income, labor productivity, and the number of motor vehicles published by the Central Bureau of Statistics (BPS) from 2001-2018. The research model was formed by adding several control variables to form a regression equation where the current year's per capita income was dependent. In contrast, the preceding year's per capita income, labor productivity, and the number of motor vehicles were independent variables. Subsequently, the regression equation was estimated by the Dynamic Ordinary Least Square (DOLS) and Fully Modified Ordinary Least Square (FMOLS) methods. The results showed a convergence of per capita income among regions. The income in more impoverished regions grew faster compared to wealthier ones. For this reason, the gap in income per capita between regions lessened significantly. Increased labor productivity and the number of motor vehicles had a positive effect on per capita income, supporting income convergence. Therefore, the transportation network needs to be improved by the government to support the mobility of workers and goods, leading to income convergence.
\end{abstract}

Keywords: convergence, income, productivity, motor vehicle

Abstraksi. Penelitian ini mengkaji terjadinya konvergensi pendapatan di Eks Karesidenan Surakarta. Data penelitian mencakup pendapatan per kapita, produktivitas pekerja, dan jumlah kendaraan bermotor yang diterbitkan oleh Badan Pusat Statistik (BPS) dari 20012018. Model penelitian dibangun dengan menambahkan beberapa variabel kontrol untuk membentuk persamaan regresi dengan variabel dependen pendapatan per kapita, sedangkan pendapatan per kapita tahun sebelumnya, produktivitas pekerja, dan jumlah kendaraan bermotor sebagai variabel independen. Selanjutnya, persamaan regresi diestimasi dengan metode Dynamic Ordinary Least Square (DOLS) dan Fully Modified Ordinary Least Square (FMOLS). Hasil penelitian menunjukkan adanya konvergensi pendapatan per kapita antar daerah. Pendapatan per kapita di daerah yang lebih miskin tumbuh lebih cepat dibandingkan daerah yang lebih kaya sehingga kesenjangan pendapatan per kapita antar daerah berkurang secara signifikan. Peningkatan produktivitas pekerja dan jumlah kendaraan bermotor berpengaruh positif pada pendapatan per kapita dan mendukung konvergensi pendapatan. Oleh karena itu, pemerintah perlu memperbaiki jaringan transportasi untuk mendukung mobilitas pekerja dan barang, yang mengarah pada konvergensi pendapatan.

Kata kunci: konvergensi, pendapatan, produktivitas, kendaraan bermotor

\section{INTRODUCTION}

Economic growth is an indicator of successful regional development marked by an increase in Gross Regional Domestic Product (GRDP). An increase in people's welfare can be realized when everyone is 
involved in the production process to generate income. The community achieves this desire in case the ownership of the resources is uniformly spread between regions. Therefore, they can take part in the production process and be compensated based on their contributions. Increased output increases consumption citizen, leading to better welfare.

Often, economic growth is not accompanied by equity. There was a significant disparity in income growth between nations (Islam, 2003). Many developing countries were getting worse, while some were experiencing high economic growth. Apart from poverty, developing countries suffer an income inequality problem. This was because the economic developments underlining macroeconomic overlooks a wide income gap between regions (Postoiu \& Buşega, 2015).

Regional economic growth is often not equitably distributed between regions. Heterogeneity of resource ownership is a significant problem of inequality between regions. The regions' abilities differ from each other; leading to disparities in income, which is shown by the difference in GDP per capita. This unbalanced development was linked to public capital (Tulumovic, 2015). In general, countries have both advantaged and disadvantaged regions. This is shown in some sectors, such as agriculture, industry, and service.

Equitable regional development does not equate to a uniform growth pattern for each region. An even regional development leads to regional economic growth based on existing capacities and potentials. Therefore, the impacts of economic growth are spread equally to the whole region. Sustainable regional growth aims to improve people's living standards in the disadvantaged regions. The local government implements sustainable regional growth through the development of agriculture, industry, trade, business sectors, necessary service facilities such as education and health.

It is vital to examine the income inequality between regions. Inequality arises because not all community members take advantage of opportunities arising from economic growth. It is related to the diversity of the community potentials, including education. In this regard, individuals with higher education and expertise take advantage of this opportunity, while others are excluded. This causes high economic growth, followed by worsening income inequality. Other factors causing economic inequalities include 1). The focus of economic activity in a region is unclear. Urban is generally narrower, yet they accommodate most of the population in terms of jobs 2). Centralization of investment allocation in urban and suburban areas is also critical. Advanced infrastructure in urban and suburban areas reduces the production cost, increasing product competitiveness. 3). Input mobility among regions has a significant contribution to economic disparity. Not smooth mobility of inputs such as labor and capital goods has an impact on the delay in production activities. For instance, the uneven distribution of agricultural facilities impacts agricultural output, which is generally located in rural areas.

Banerjee \& Jarmuzek (2010) examined regional differences of the Slovak Republic. The study established that regional inequalities, including GDP per capita, labor productivity, and labor use, have risen since 2000, coinciding with Slovakia's negotiations on entry into the EU. However, there was an advance in Total Factor 
Productivity, the main driving force of growth in all sectors. According to Kim et al., (2003), there was a positive link between the variation of regional income and spatial distribution of decentralization tools, including employment, educational services, the infrastructure, and the knowledge network.

Income disparities also arise due to differences in economic potential between regions, including infrastructural dissimilarities. Generally, urban areas have better infrastructure, making them investment destinations. Better infrastructure leads to lower production costs, which attract factories. Therefore, the investment appears to focus on locations near markets (Lall et al., 2004). Transportation costs can be reduced where a firm is located near a market or a port, enhancing export trade. Also, infrastructural development improves labor productivity and vice versa.

There is a variation in the population's ability between regions. Since, urban residents have higher education and skills, which benefits them in terms of agglomeration to work in productive sectors. They can secure a job in the secondary or tertiary sector with high labor productivity and a wage. Conversely, rural residents lack adequate education and skills, hence cannot secure jobs in productive sectors. They are forced to work in the primary sector, especially agriculture, with low labor productivity and wage. The differences in education levels between urban and rural residents lead to welfare imbalances.

Furthermore, the development of transportation technology supports high population mobility. With better transportation technology, rural residents access better education infrastructure in urban areas. The ownership of transportation means has increased with the rise in community income. This allows workers to secure jobs in areas with higher compensation. In the same way, unemployed people in a region may find jobs in other areas due to ownership of transportation means. Additionally, there are changes in transportation patterns due to the increase in community income. Motorcycles dominate the current transportation services for short-haul trips, while buses and cars are used for longer trips (Dewanti et al., 2014).

Vehicles enable rural residents to move for better jobs with higher compensation. A high wage raises earnings relatively faster, leading to rapid income convergence. Also, the predicted convergence rate is slightly increased by the labor movement. Addition of a net migration also improves income convergence (Ozgen et al., 2010). Therefore, an impoverished region can pursue per capita income from the wealthy ones, leading to income convergence and disparity between regions (Barro \& Martin, 2004).

Apart from infrastructure, human capital needs to be addressed. This aspect relates to the qualitative dimensions of human resources, such as expertise and skills that determine labor productivity. It is an essential factor for economic growth which, in the long run, cannot depend on physical input rather than human capital, including innovation and education (Di Liberto, 2008: Pelinescu, 2015). The existence of human capital complements physical capital to sustain economic growth (Pablo-Romero \& Gómez-Calero, 2013). This experience shows that lags in human capital hamper the high economic growth of a country. With an improvement in labor, there can be an increased amount of social capital to 
raise economic activity. A multiplier effect is realized with the development of the labor force in disadvantaged areas. Higher economic growth rates make the lagging regions grow faster than the developed regional economy. Underdeveloped regions may catch up with developed ones, lessening income inequality (Barro \& Martin, 2004).

According to Neo-Classical growth theory, inequality of per capita income between regions decreases with economic development activities. A lagging region could grow faster as compared, catching up with the income of the rich ones (Barro \& Martin, 2004). Stable conditions are achieved as a result of the equilibrium mechanism based on constant returns to scale. In this process, the short-term disparity in economic growth due to differences in production technology diminishes, a difference that gradually disappeared due to a free movement of input between regions. This leads to income convergence.

There are two convergence concepts, $\sigma$ and $\beta$. The $\sigma$ convergence refers to the disparities that can be calculated by standard disparities of per capita income between regions. When the value declines, there is an income convergence and vice versa. According to the $\beta$-convergence principle, in terms of income per head, a poor economy may keep pace with a prosperous one (Barro \& Martin, 2004). Moreover, the $\beta$ convergence definition can be divided into 2: absolute and conditional. Absolute convergence refers to the metric based only on the initial level of income. Its estimation takes place without factoring the control variables representing each region's characteristics. All areas are considered under the same stable conditions where no other variables are included in the convergence equation. Conversely, the conditional convergence calculation involves the effects of variables calculated at each zone's state. These, in each region, are determined under conditional convergence equations based on the steadystate conditions.

Some research partially supports the Neo-Classical growth theory, while others do not. The research in rural and suburban areas indicate there is an income convergence (Kosfeld et al., 2006; Gyawali et al., 2008). Rural and underdeveloped suburban areas can expand relatively quicker, catching up developed regions, leading to an income convergence process. Human capital and employment are relevant to control the convergence processes. However, several studies show the occurrence of income divergence (Hammond, 2006). The strongest tendencies to diverge were evident in nonmetropolitan areas with larger urban centres and small towns. Differences in human capital have influenced these regions' relative performance in the last three decades, suggesting a role for agglomeration economies in the trend toward divergence. Additionally, Chikte (2011) studied sub-national income convergence in India. The results indicated that per capita income of the 15 states in the study sharply diverged. Throughout, the was a rise in the standard deviation of the net national product showing no convergence in the pre- or post-reform era.

Furthermore, the study included the Surakarta Ex-Residency area of 6 regencies and one city. The solo economy differed from other regions since it encourages the development of the tertiary sector, which dominates the formation of gross regional domestic product (GRDP). The city is a hub of some sectors such as the trade, hotel and 
restaurant sector, transportation and communication, financial, rental and business, as well as the services sector. There is a possibility of income convergence in the Surakarta ExResidency, regardless of the economic differences in the regions. This is encouraged by the social interaction among residents in this area. This study examines whether there is an income convergence in the Surakarta Ex-Residency.

\section{RESEARCH METHOD}

The study used data from the Central Bureau of Statistics (BPS), including per capita income, labor productivity, and motor vehicle number for 2001-2018. The starting point of the research was in 2001, when the regional autonomy takes place. The final point is in 2018 with the latest BPS data. Additionally, this research used city-based research data collection, illustrating the presence or absence of income convergence closely. Eliminating bias due to aggregation can be achieved by narrowing the research area. Microdata analysis was used to represent the detailed conditions of each region for precise policies to be designed according to the real economic potential.

Per capita income is the value of regency gross regional domestic product (GRDP) in constant 2010 prices divided by the population. The ratio of GRDP in the constant prices of 2010 to the employed person's number reflected productivity was measured by the value of regency gross regional domestic product (GRDP) in the constant prices of 2010 divided by the number of people employed. Similarly, the motor vehicle number was measured as the ratio of the four-wheeled and six-wheeled motor vehicles per 1000 inhabitants.
This study examines income convergence in the Surakarta Ex-Residency area and the variables that affected it from 2001 to 2018. The analysis is in the form of panel data with various advantages (Baltagi, 2005). For instance, it can control the heterogeneity of regions, provide more freedom, and reduces variable collinearity. Before further analysis, it should be

evaluated for co-integration of some variables. In case co-integration occur, there is a desired long-term balance between the economic variables. This study used the Kao method. Moreover, to estimate the possibility of convergence, this study used the Dynamic Ordinary Least Square (DOLS) and Fully Modified Ordinary Least Square (FMOLS). These methods were chosen because they are superior to OLS method (Arize et al., 2015). The following equation was used in the income convergence process.

$$
\begin{aligned}
\Delta I N C M_{i t}= & \alpha_{i}+\beta \operatorname{INCM}_{i, t-1}+\gamma P R O D_{i t}+ \\
& \delta V E H C_{i, t}+e_{i, t}
\end{aligned}
$$

Where INCM is the per capita income, PROD is labor productivity, and VEHC is a number of the motor vehicle.

Equations (1) is an overview of the income convergence. This occurs when the coefficient is negative $(\beta<0)$. The speed of convergence $\lambda$ can be calculated according to $\lambda=-\ln (1+\beta) / \mathrm{T}$, with $\mathrm{T}$ denoting the length of time series data (Paas et al., 2007).

\section{RESULTS AND DISCUSSION \\ Results}

Descriptive statistics were used to determine whether there was the inequality between regions. This help explains specific data characteristics. Table 1 show descriptive statistical indicators of the 
variables. Based on the descriptive data, and there is inequality existed between the difference was significant to indicate the regions in the Surakarta Ex-Residency. This

imbalance between the developed and the lagging regions, reflected in the value range of per capita income, labor productivity, and motor vehicle number.

Table 1.

Descriptive Statistic

\begin{tabular}{lccc}
\hline & $\begin{array}{c}\text { Per capita } \\
\text { Income }\end{array}$ & $\begin{array}{c}\text { Labor } \\
\text { Productivity }\end{array}$ & $\begin{array}{c}\text { Motor } \\
\text { Vehicle }\end{array}$ \\
\hline Mean & 20.881 & 43.038 & 18.768 \\
Median & 17.753 & 36.269 & 12.751 \\
Maximum & 64.698 & 129.634 & 94.416 \\
Minimum & 9.477 & 20.023 & 1.906 \\
Standard Deviation & 11.011 & 22.402 & 15.889 \\
\hline
\end{tabular}

Source: Central Bureau of Statistics (BPS), 2001-2018

The subsequent analysis is a co- the same sign regression coefficient mark, integration test. The Kao model had a value even when the values were different. All the of-9,682 with a probability of less than independent variables in both models were 0.05 . This implied a co-integration between significant at $\alpha=5 \%$. Subsequently, the variables. The resulting residual was coefficient of determination $\left(\mathrm{R}^{2}\right)$ in the stationary in I (0) due to an existing linear DOLS model of 0.726 showed that stationary combination in a variable set. As variations in the independent variables desired in economic theory, the models explained 72.6 per cent of the per capita have a long-term equilibrium relationship. income variation. In the FMOLS model, the There was consistency in the long run value of the coefficient of determination between variables.

Moreover, the estimation results of the Dynamic Ordinary Least Square and Fully Modified Ordinary Least square were similar. In both models, $\mathrm{t} \beta, \gamma$, and $\delta$ have variations in the independent variables explained 51.9 per cent of the per capita income variation (Table 2).

Table 2.

The Estimation Result

\begin{tabular}{clcc}
\hline Number & Variable & DOLS & FMOLS \\
\hline 1 & Per Capita Income & $-0.229^{*}$ & $-0.410^{*}$ \\
& Previous Year & $(0.066)$ & $(0.051)$ \\
2 & Labor Productivity & $0.217^{*}$ & $0.375^{*}$ \\
& & $(0.057)$ & $(0.041)$ \\
3 & \multirow{2}{*}{ Motor Vehicle } & $0.206^{*}$ & $0.351^{*}$ \\
& & $(0.084)$ & $(0.082)$ \\
\hline \multirow{2}{*}{$\mathrm{R}^{2}$} & 0.726 & 0.519 \\
& & 112 & 112 \\
\hline
\end{tabular}

Source: Central Bureau of Statistics (BPS), processed

Note $*$ indicates significant at $(\alpha=5 \%)$

Numbers in parentheses are Standard Errors

Dependent variable: Change in per capita income 


\section{Discussion}

Solo City and Sukoharjo Regency have high capita income. The high income in Solo municipality is attributed to its position as a business centre. Its economy is dominated by the tertiary sector, which is supported by skilled and educated workers. The characteristics of this service sector require workers with specific expertise to encourage value addition, raising gross regional domestic product. This leads to a higher per capita income. Moreover, the Sukoharjo economy is comparatively dominated by the secondary sector. This efficiency-oriented leads to competitiveness and increased market share. Having specific skills is a requirement to obtain jobs in this sector. Skilled labor encourages high productivity, bringing a positive impact on the per capita income.

The role of the primary sector, such as agriculture, is still relatively high in other regions and holds a large workforce. In Boyolali and Wonogiri regencies, for instance, it was still around 30 per cent in 2015. However, the conversion of some farming lands to non-farming has resulted in a decrease in land ownership by farmers. Small farming profits support significant land conversion. The agricultural sector is facing a labor surplus problem, lowering labor productivity. This has an impact on the little value-added in the farming sector, leading to low per capita income.

There was an income convergence in the Surakarta Ex-Residency, even with the imbalance in the income per capita. The study showed that the coefficient of per capita income was negative. The lagging regions expanded more quickly to catch up with advanced ones. The gap in per capita income between regions disappeared. Investment plays a critical role in overcoming economic disparity. This shows that additional capital goods encourage an increase in capital intensity, where each worker gets more massive production facilities. It improves labor productivity, leading to higher value-added.

Most investments in the Surakarta ExResidency were domestic. From 2016 to 2018, Sukoharjo, Karanganyar, Sragen, and Boyolali Regencies received a lot of domestic investments, while Solo City and Wonogiri Regency received the lowest. Sukoharjo, Karanganyar, Sragen, and Boyolali regions had high economic potential, attracting more investors. This adds to the capital goods in these areas. An increase in domestic investment increases capital intensity leading to higher labor productivity. Consequently, the addedvalue improves, encouraging an increase in per capita income. This overcomes income disparity in the regions.

Different levels of convergence speed were produced by the DOLS and FMOLS models. The annual rates of convergence were 1.401 and 2.931 per cent for the DOLS and FMOL models, respectively. The income convergence in the Surakarta Ex-Residency was slow. In comparison, the income convergence speed by involving infrastructure variables in Europe is 2 per cent per year (Del Bo et al., 2010). Meanwhile, Udjianto et al. (2018) established the annual speed of productivity convergence in Gunungkidul to be 4.5 per cent. This convergence speed is different from previous research due to the differences in the selection of variables used in research, analytical methods and the scope of research.

The differences in city and regency characteristics contributed to the slow income convergence. The Solo economy is dominated by the tertiary sector while the secondary sector dominates the economy of 
the Sukoharjo Regency. The high added value was recorded in the primary and secondary sector, reflecting a high per capita income in Solo City and Sukoharjo Regency. In other regions, the primary sector plays a significant role with low added value. Value-added is different in each economic sector. In the secondary and tertiary sector, the high value-added produced is supported by educated and skilled workers. In contrast, the valueadded in the primary sector is low due to unskilled labor. In general, the inequality of value-added slowed the process of income convergence.

A convergence of income can be catalyzed by faster growth of disadvantaged regions. The government needs to encourage investment in some regions to increase added value. The infrastructure and economic potential of a place determine the choice of investment location. Therefore, improvement in the quality of infrastructure is vital. A rise in community income has led to an increase in the number of vehicles at a relatively fixed length of roads, resulting in congestion. In consequence, a smooth supply chain and production are disrupted. An improved transportation network encourages easier transportation of raw materials and products.

The coefficients of labor productivity were 0.217 and 0.375 in the DOLS and FMOLS models, respectively. This means that with a 1 per cent productivity increase, the per capita income rises by 0.217 per cent and 0.375 per cent, respectively. These findings are consistent with Nakamura et al., (2019) that resource reallocation drives economic growth in Japan.

An increase in labor productivity showed more output per worker. Labor productivity is an indicator of a company's performance. A direct relationship exists between the wage rate and labor productivity. An increase in labor productivity results in increased wages, making workers more prosperous. This may be indicated by a rise in worker's contributions in generating output.

In the lagging regions, high labor productivity generated a higher output than in advantaged ones. The high economic growth helps keep pace with more advanced areas. From this observation, an increase in labor productivity supports income convergence. Furthermore, labor productivity is a critical factor contributing to economic growth. It affects economic growth by raising production efficiency and reducing input costs.

Increasing labor productivity requires resource reallocation. For long, the labor surplus has been a problem in the agricultural sector. This has led to low labor productivity in this sector, creating a need for the government to develop other sectors, such as the industry and services sector. These sectors can accommodate excess workers in the agricultural sector. The industrial and service sectors' wage rates are higher than those in the agricultural sector, attracting some agricultural workers. The reduction of labor in the agricultural sector leads to an increase in labor productivity in this sector.

The development of the industry and services sector is made through the utilization of unused land. This is carried out through the construction of accessible road infrastructure. Easier accessibility minimizes transportation costs, thereby raising product competitiveness. Product competitiveness is, therefore, critical in improving labor productivity and economic growth.

From both the DOLS and FMOLS models, a motor vehicle number has a 
positive impact on per capita income. The coefficient of motor vehicles was 0.206 and 0.351 for the DOLS and FMOLS, respectively. An increase in the number of vehicles by 1 per cent leads to a per capita income rise of 0.206 per cent and 0.351 per cent in the DOLS and FMOLS models, respectively. These results are in line with Yang et al. (2016).

The surge in the ratio of vehicle number per 1000 population showed increased transportation models, supporting the mobility of workers and goods. Smooth mobility enabled residents to work in other areas with higher wages. Also, unemployed residents could secure jobs in other areas due to excellent transportation. Therefore, an excellent transportation network supports increases employment opportunities and income.

Smooth transportation encourages an equal distribution of economic activities. It attracts the location of companies in the local regions. Improved transportation promotes the smooth supply of raw materials and support marketing. This lessens production costs, enhancing high competitive products and maintain peak performance.

Smooth transportation facilitates the growth of some micro, small, and medium enterprises (MSME). Capital has been a constrain for MSME, including the need for strategic locations in the suburbs. Easier transportation allows MSME to operate in the sub-district or rural areas with cheap rent. This two factors lower production costs, leading to competitive products which drive MSME performance.

Improved performance of the industrial sector increases income, promoting the development of the service sector. Highincome people need services such as banking, tourism, hotels, and restaurants. This has led to the development of the service sector in the areas of banks, hotels, and restaurants. An increase in tourism activities has resulted in the development of travel agents that serve tourist trips. Subsequently, the need for socializing has encouraged the development of businesses in the culinary, such as restaurants, cafes, and food stalls that operate in tourism centres. Therefore, excellent transportation improves employment opportunities and output, raising per capita income. This means that in a lagging region per capita grow faster to catch up with more advanced regions, promoting income convergence. It also accelerates that economic activity in underdeveloped regions. An efficient transportation system solves the problem of high-cost distribution.

\section{CONCLUSION}

This study shows there was a convergence of per capita income in the Surakarta Ex-Residency. Increased labor productivity and motor vehicle improve per capita income, which encourages income convergence. Per capita income in lagging regions grew relatively faster, lessening the gaps. The government needs to improve the quality of human resources through education, training, and courses. The quality of human resources optimizes labor productivity, especially in lagging regions. Importantly, cooperation between local governments and other institutions can be realized in integrated programs. Moreover, the improvement of the transportation network and the mobility of workers and goods is imperative. It reduces the production cost, leading to higher competitiveness and performance. 


\section{REFERENCES}

Arize, A. C., Malindretos, J., \& Ghosh, D. (2015). Purchasing power parity-symmetry and proportionality: Evidence from 116 countries. International Review of Economics \& Finance, 37(C), 69-85.

Baltagi, B. (2005). Econometric Analysis of Panel Data (3rd ed.). John Wiley and Sons.

Banerjee, B., \& Jarmuzek, M. (2010). Economic Growth and Regional Disparities in the Slovak Republic. Comparative Economic Studies, 52(3), 379-403.

Barro, R. J., \& Martin, X. S. (2004). Economic Growth (2nd ed.). MIT Press.

Chikte, R. P. (2011). Income Convergence and Regional Growth in India Before and After the Economic Liberalization,. South Asia Economic Journal, 12(2), 239-269.

Del Bo, C., Florio, M., \& Manzi, G. (2010). Regional Infrastructure and Convergence: Growth Implications in a Spatial Framework. Transition Studies Review, 17(3), 475493. https://link.springer.com/article/10.1007/s11300-010-0160-4

Dewanti, Parikesit, D., \& Djunaedi, A. (2014). Perkembangan Layanan Transportasi Perdesaan Pada Wilayah Berbukit. Jurnal Teknosains, 3(2), 91-101.

Di Liberto, A. (2008). Education and Italian regional development. Economics of Education Review, 27(1), 94-107.

Gyawali, B., Burkenya, J., Schelhas, J., \& Fraser, R. (2008). Income Convergence in a Rural, Majority African-American Region. The Review of Regional Studies, 38(1), 4565 .

Hammond, G. W. (2006). A Time Series Analysis of U.S. Metropolitan and Nonmetropolitan Income Divergence. Annals of Regional Science, 40(1), 81-94. https://link.springer.com/article/10.1007/s00168-005-0029-3

Islam, N. (2003). What Have We Learnt From the Convergence Debate? Journal of Economic Surveys, 17(3), 309-362. https://doi.org/doi=10.1.1.457.1741\&rep=rep1\&type=pdf

Kim, E., Hong, S. W., \& Ha, S. J. (2003). Impacts of national development and decentralization policies on regional income disparity in Korea. The Annals of Regional Science, 37(1), 79-91.

Kosfeld, R., Eckey, H. F., \& Dreger, C. (2006). Regional productivity and income convergence in the unified Germany, 1992-2000. Regional Studies, 40(7), 755-767. https://doi.org/10.1080/00343400600959322

Lall, S., Shalizi, Z., \& Deichman, U. (2004). Agglomeration Economies and Productivity in Indian Industry. Journal of Development Economics, 73(2), 643-673. https://doi.org/https://doi.org/10.1016/j.jdeveco.2003.04.006

Nakamura, K., Kaihatsu, S., \& Yagi, T. (2019). Productivity Improvement and Economic Growth: Lessons From Japan. Economic Analysis and Policy, 62, 57-79. 
Ozgen, C., Nijkamp, P., \& Poot, J. (2010). The effect of migration on income growth and convergence: Meta-analytic evidence. Papers in Regional Science, 89(3), 537-561. https://doi.org/10.1111/j.1435-5957.2010.00313.

Paas, T., Kuusk, A., Schlitte, F., \& Vork., A. (2007). Econometric Analysis of Income in Selected EU Countries and Their NUT 3 Level Regions. In Tartu University Press. Tartu. Turkey.

Pablo-Romero, M., \& Gómez-Calero, M. de la P. (2013). A Translog Production Function for The Spanish Provinces: Impact of The Human and Physical Capital in Economic Growth,. Economic Modelling, 32, :77-87.

Pelinescu, E. (2015). Procedia Economics and Finance. The Impact of Human Capital on Economic Growth, 184-190.

Postoiu, C., \& Bușega, I. (2015). Inter-Regional Disparities in the European Union. Romanian Review of Regional Studies, XI(1), 15-17. http://rrrs.reviste.ubbcluj.ro/arhive/Artpdf/v11n12015/RRRS11120151.pdf

Tulumovic, V. (2015). Models of Regional Aspect and Development Underdeveloped Regions. Journal of International Social Research, 8(40), 806-806. https://doi.org/10.17719/jisr.20154013960

Udjianto, D. W., Susanto, J., \& Purwiyanta, P. (2018). Infrastructure and Labour Productivity Convergence in Gunungkidul Region. JEJAK: Jurnal Ekonomi Dan Kebijakan, $11(2)$, 356-374. https://doi.org/doi:https://doi.org/10.15294/jejak.v11i2.16057

Yang, F., Pan, S., \& Yao, X. (2016). Regional convergence and sustainable development in China. Sustainability (Switzerland), 8(2), 1-15. https://doi.org/10.3390/su8020121 